\title{
TRANSFORMATION OF LAND RELATIONS IN THE CONTEXT OF FORMATION AND REALIZATION OF THE STATE AGRICULTURAL POLICY
}

\author{
M. Huba, Y. Barsuk \\ Kherson State Agricultural University
}

\begin{tabular}{l}
\multicolumn{1}{c}{ Key words: } \\
Land relations \\
Land market \\
Agrarian policy \\
Transformation of the \\
structure of the land fund \\
Land reform \\
\hline Article history: \\
Received 12.01.2018 \\
Received in revised form \\
22.01 .2018 \\
Accepted 05.02.2018 \\
\hline Corresponding author: \\
M. Huba \\
E-mail: \\
gubamarina16@gmail.com
\end{tabular}

\section{ABSTRACT}

In the article the process of transformational changes taking place in land relations of the subjects of the agrarian sector of the economy as the basic factor of formation and implementation of the agrarian policy of the state is researched. The institutional component of the agrarian policy of the state is considered in order to determine the guidelines for the further development of land relations in the agrarian sector of the ukrainian economy. An analysis of the normative and legal provision of state regulation of land relations shows that since the restoration of Ukraine's independence, a whole range of subordinate legal acts aimed at regulation and development of land relations and the completion of land reform has been adopted.

The features of land use from the point of view of forms of ownership and forms of management are revealed. The tools and mechanisms of the regulatory influence of the state on their implementation in the conditions of reforms are determined. It has been established that, despite such a significant amount of adopted laws and regulations in the field of land reform, the authorities empowered to carry out land reform (especially at the local level) faced the following main difficulties: a number of legislative acts are contradictory, which complicates their implementation, and respectively, land reform; redistribution of land, granting and securing them into property and using require significant amount of work and mainly extent depend on the amount of funding.

The normative-legal documents, which specify the main directions, strategic goals and tasks of the state social policy in the field of land relations, are considered. However, the formation of the regulatory framework must be directed at deepening and completing the land reform and building, first of all, civilized market land relations and ensuring the social development of the village.

It is proved that the improvement of land relations in the agrarian sector at the local, regional and national levels is a prerequisite for the formation and implementation of agrarian policy focused on the development of competitive agrarian production and rural areas.

DOI: $10.24263 / 2225-2924-2018-24-1-5$ 


\title{
ТРАНСФОРМАЦІЯ ЗЕМЕЛЬНИХ ВІДНОСИН У КОНТЕКСТІ ФОРМУВАННЯ I РЕАЛІЗАЦІЇ ДЕРЖАВНОЇ АГРАРНОЇ ПОЛІТИКИ
}

\author{
М.I. Губа, Ю.В. Барсук \\ Херсонський державний аграрний університет
}

У статті досліджено прочес трансформаційних змін, що відбуваються у земельних відносинах суб'єктів агарного сектору економіки як базового чинника формування та реалізаиії аграрної політики держави. Розглянуто інституиійну складову аграрної політики держави з метою визначення орієнтирів подальшого розвитку земельних відносин в аграрному секторі економіки України. Аналіз нормативно-правового забезпечення державного регулювання земельних відносин свідчить про те, щзо з часу відновлення незалежності Украӥни прийнято иілий спектр підзаконних нормативноправових актів, спрямованих на регулювання та розвиток земельних відносин та завершення земельної реформи.

Виявлено особливості землекористування з точки зору форм власності та форм господарювання. Визначено інструменти і механізми регуляторного впливу держави на їх впровадження в умовах проведення реформ. Встановлено, що, незважаючи на значний обсяг прийнятих законів та підзаконних актів у сфері реформування земельних відносин, органи, які уповноважені проводити земельну реформу (особливо на місиевому рівні), зіткнулися з такими основними труднощами: ряд законодавчих актів суперечливі, щзо ускладнює їх реалізацію, а відповідно, і проведення земельної реформи; перерозподіл земель, надання та закріплення їх у власність та користування потребують значних обсягів робіт $і$ значною мірою залежать від обсягів фiнансування.

Розглянуто нормативно-правові документи, у яких визначено основні напрями, стратегічні иілі та завдання державної соціальної політики у сфері земельних відносин. Однак формування нормативно-правової бази необхідно спрямувати на поглиблення й завершення земельної реформи та розбудову насамперед иивілізованих ринкових земельних відносин $i$ забезпечення соціального розвитку села.

Доведено, що удосконалення земельних відносин в аграрному секторі на локальному, регіональному і загальнодержавному рівнях є необхідною умовою формування й реалізачії аграрної політики, зорієнтованої на розвиток конкурентоспроможного аграрного виробництва та сільських територій.

Ключові слова: земельні відносини, земельний ринок, аграрна політика, трансформачія структури земельного фонду, земельна реформа.

Постановка проблеми. Аграрна економіка України вступила в новий етап активних трансформацій, спрямованих на завершення формування інституційної системи й аграрної реформи. Трансформації, які відбуваються в земельних відносинах, $\epsilon$ результатом інституційних змін. Формування ринко- 
вих відносин в економіці країни сприяло виникненню нових умов розвитку аграрної сфери через інститути власності, ринку, оренди, конкуренції, ціноутворення, вартості. У зв'язку з цим в Україні здійснено важливі етапи реформування земельних відносин: проведено роздержавлення і грошову оцінку земель, приватизацію сільськогосподарських угідь. На новій організаційно-правовій основі сформовані підприємства ринкового типу. Передача державою сільськогосподарських угідь у приватну власність громадян стала передумовою формування ринкових земельних відносин. Однак слід констатувати, що на сьогодні земельна реформа в Україні далека від свого логічного завершення. Більшість найважливіших цілей земельної реформи, визначених законодавчо, так і не було досягнуто. Держава не забезпечила остаточного вирішення проблем справедливого розподілу земель, раціонального землекористування, дотримання екологічних норм законодавства.

Аналіз останніх досліджень і публікацій. Проблемам ефективного використання земельних ресурсів в Україні, розвитку ринку землі присвячено наукові праці провідних учених, серед яких: А. Даниленко, П. Пресіч, О. Олійник, П. Саблук, Т. Сидоренко, А. Сохнич, М. Ступень, Г. Черевко, І. Юхновський, А. Третяк та інші. Відзначаючи внесок цих та інших вчених у розвиток системи земельних відносин, необхідно зазначити, що в сучасних умовах ці відносини настільки динамічні і суперечливі, що вимагають подальшого дослідження.

Сьогодні ведуться наукові розробки щодо подальшого розвитку земельних відносин, зокрема, формування та розвитку ринку земель і його інфраструктури, методики нормативно-грошової оцінки сільськогосподарських земель в умовах формування ринкових відносин, ефективного та еколого-безпечного використання земель сільськогосподарського призначення, організації державного контролю над їх екологічним станом. Відзначаючи позитивні зрушення в розвитку земельних відносин, слід підкреслити актуальність існуючих проблем, на розв'язання яких спрямована стаття.

Метою статті $\epsilon$ розгляд питань, пов'язаних з концептуальними напрямами земельної реформи держави як базової складової аграрної політики в цілому, удосконаленням системи управління землекористуванням, соціально-економічними проблемами розвитку сільських територій у контексті земельних відносин.

Викладення основних результатів дослідження. Перехід до цивілізованих форм ринкових відносин передбачає реформування суспільства 3 багатьох напрямків соціально-економічного розвитку країни. Найважливішим із них $€$ вдосконалення системи земельних відносин та ії інституційного забезпечення. Трансформація земельних відносин у науці і практиці розглядається як ключовий елемент аграрної реформи. Сутність ринкових перетворень в аграрному секторі передбачає зміну основ земельної власності, форм використання земельних ресурсів з урахуванням регіональної специфіки землекористування. Трансформація земельних відносин в умовах ринкового середовища функціонування вітчизняної системи землекористування перетворилась в повномасштабну земельну реформу, яка й досі повністю не завершилась. Але головне завдання реформування архаїчних відносин щодо форм власності на землю стало об’єктивним процесом [1]. 
Земельна реформа в Україні триває вже 26 років. Утім, незважаючи на ряд реалізованих заходів (величезні площі передані у приватну власність, розпайовані), реформа ще далека від завершення: ринок землі сільськогосподарського призначення не існує, значна частина ринку оренди знаходиться «в тіні», а декілька категорій землі не мають чіткого правового статусу або ж використовуються непрозоро. За період здійснення земельної реформи в Україні відбулася поетапна реалізація комплексу тактичних і стратегічних організаційно-економічних заходів, які забезпечили перехід до нової системи земельних відносин.

На першому етапі земельної реформи (1991-1993 рр.) відбувся перехід від адміністративно-планових до ринкових відносин в аграрному секторі, який характеризувався законодавчим визнанням [2-5], поряд 3 державною, колективної та приватної власності на землю; створенням правового поля та умов для реформування економічних відносин на селі шляхом демонополізації державної власності; проведенням приватизації державного майна i землі; формування реального господаря-власника на селі; розвиток вільного підприємництва; створення належних умов для прибуткового господарювання сільськогосподарських підприємств, що, у свою чергу, повинно забезпечити підвищення рівня життя людей у сільській місцевості та продовольчої безпеки в Україні. Процес приватизації забезпечив безоплатну передачу селянам сільськогосподарських угідь, земель запасу та земель резервного фонду, які раніше знаходилися у державній власності, у приватну власність громадянам 3 метою ведення особистих селянських господарств і фермерських господарств. Таким чином, на цій основі сформувалися передумови для розвитку конкуренції та багатоукладності у сільському господарстві України.

На другому етапі реформування земельних відносин (1994-1999рр.) відбулося формування пайового земельного фонду, який розподілявся між членами колективних сільськогосподарських підприємств і організацій, включаючи пенсіонерів з їх числа, на земельні частки (паї), в їх умовних (кадастрових) гектарах, із зазначенням їх вартості, та із можливістю подальшого виділення земельної ділянки в натурі (на місцевості), з видачею на них відповідного документа-сертифіката, а пізніше - державного акта на право на земельну частку (пай) [6]. У результаті майже 6 млн громадян України, які були членами колективних сільськогосподарських підприємств, отримали сертифікати на право на земельну частку (пай), що пізніше були замінені на державні акти на право приватної власності на землю.

Наступним кроком реформування земельних відносин стало правове врегулювання орендних земельних відносин [7]. 31 січня 1999 року в Україні запроваджено фіксований сільськогосподарський податок на землю та визнаний статус орендної плати.

Третій етап реформування земельних відносин (2000 p. - донині) передбачав створення на базі колективних і недержавних сільськогосподарських підприємств нових агроформувань ринкового спрямування та організацію належного державного контролю за формуванням і функціонуванням ринку земель сільськогосподарського призначення, їх екологічним станом та раціо- 
нальним використанням [8]. Однак відсутність належного правового регулювання земельних орендних відносин сповільнила процеси реорганізації колективних сільськогосподарських підприємств у ринкові формування.

У результаті здійснення земельної реформи в Україні відбулись докорінні зміни у земельних відносинах 3 огляду на форми власності та господарювання. Так, якщо на кінець 1991 р. весь земельний фонд України перебував у державній власності, то на початок 2017 р. питома частка сільськогосподарських угідь у користуванні сільськогосподарськими підприємствами державної власності становила 2,6\%, недержавної власності - 56,9\%, населення - 43,1\% (табл. 1). Усього станом на 1 січня 2017 року земельний фонд України становить 60,3 млн гектарів, або близько 6\% території Європи. Сільськогосподарські угіддя становлять близько 19\% загальноєвропейських, у тому числі рілля - близько 27\%. Показник площі сільськогосподарських угідь у розрахунку на одну особу є найвищим серед європейських країн i становить 0,9 гектара, у тому числі 0,7 гектара ріллі (середній показник європейських країн - 0,44 і 0,25 гектара відповідно).

Розглянемо у таблиці площу та розподіл сільськогосподарських угідь за землевласниками і землекористувачами в Україні.

Таблиия. Площа сільськогосподарських угідь за категоріями землевласників і землекористувачів України, розроблено авторами за даними [9]

\begin{tabular}{|c|c|c|c|c|c|c|c|c|c|c|}
\hline \multirow{3}{*}{ Показники } & \multicolumn{2}{|c|}{1990} & \multicolumn{2}{|c|}{2000} & \multicolumn{2}{|c|}{2005} & \multicolumn{2}{|c|}{2010} & \multicolumn{2}{|c|}{2016} \\
\hline & \begin{tabular}{|c|} 
Площа \\
с.-г. \\
угідь
\end{tabular} & $\begin{array}{c}\text { До } \\
\text { загаль } \\
\text { ної } \\
\text { площі } \\
\text { с.-г. } \\
\text { угідь }\end{array}$ & $\begin{array}{c}\text { Площа } \\
\text { с.-г. } \\
\text { угідь }\end{array}$ & \begin{tabular}{|c|} 
До \\
загаль- \\
ної \\
площі \\
с.-г. \\
угідь \\
\end{tabular} & $\begin{array}{c}\text { Площа } \\
\text { с.-г. } \\
\text { угідь }\end{array}$ & \begin{tabular}{|c|} 
До \\
загаль- \\
ної \\
площі \\
с.-г. \\
угідь \\
\end{tabular} & $\begin{array}{c}\text { Площа } \\
\text { с.-г. } \\
\text { угідь }\end{array}$ & $\begin{array}{c}\text { До } \\
\text { загаль } \\
\text { ної } \\
\text { площі } \\
\text { с.-г. } \\
\text { угідь }\end{array}$ & $\begin{array}{c}\text { Площа } \\
\text { с.-г. } \\
\text { угідь }\end{array}$ & \begin{tabular}{|c} 
До \\
загаль \\
ної \\
площі \\
с.-г. \\
угідь
\end{tabular} \\
\hline & тис. га & $\%$ & тис. га & $\%$ & тис. га & $\%$ & тис. га & $\%$ & тис. га & $\%$ \\
\hline $\begin{array}{l}\text { Усі категорії } \\
\text { господарств }\end{array}$ & 41721 & 100 & 40308 & 100,0 & 37322 & 100,0 & 36555 & 100,0 & 36453 & 100,0 \\
\hline $\begin{array}{c}\text { Сільсько- } \\
\text { господарські } \\
\text { підприємства }\end{array}$ & 39156 & 93,9 & 34065 & 84,5 & 23502 & 63,0 & 20864 & 57,1 & 20747 & 56,9 \\
\hline державні & 29099 & 69,7 & 32067 & 79,6 & 22214 & 59,5 & 1048 & 2,9 & 937 & 2,6 \\
\hline недержавні & 10057 & 24,1 & 1997,7 & 5,0 & 1288,7 & 3,5 & 19816 & 54,2 & 19810 & 54,3 \\
\hline $\begin{array}{c}\text { Господарства } \\
\text { населення } \\
\end{array}$ & 2565 & 6,1 & 6243,2 & 15,5 & 13819 & 37,0 & 15690 & 42,9 & 15706 & 43,1 \\
\hline
\end{tabular}

Основними тенденціями трансформації структури земельного фонду за 1991-2017 pp. за основними власниками землі та землекористувачами $є$ зменшення площ земель у власності та користуванні недержавних і державних сільськогосподарських підприємств (це стосується підприємств усіх організаційно-правових форм господарювання) та збільшення площ земель, які надані у власність і користування громадянам, а також земель селянськофермерських господарств. Сьогодні очевидно, що очікування і результати, пов'язані 3 проведенням цієї реформи, є суперечливими. Серед основних негативних наслідків земельної реформи такі: 
- виникнення та розвиток процесів надмірної консолідації землі в рамках одного вертикально інтегрованого агроформування;

- негативні структурні зрушення галузевої структури агровиробництва: частка продукції рослинництва досягає в останні роки 70\% порівняно $352 \%$ на початку реформи;

- порушення раціональної структури посівних площ і чергування сільськогосподарських культур, зниження вмісту гумусу в грунті та зниження його родючості.

- занепад, а подекуди зникнення цілих галузей аграрного виробництва та галузей, що з ними технологічно й організаційно споріднені;

- зменшення кількості робочих місць у сільському господарстві, зубожіння сільських жителів, відсутність рівних можливостей реалізації їх професійних і соціальних прав. Кількість домогосподарств, чий дохід на людину складає менше прожиткового мінімуму в сільській місцевості майже 25\% проти 10,5\% в містах, причому жителі сільських територій - це майже третина (31\%) від усього населення України;

- погіршення соціально-економічного розвитку сільських територій.

3 метою проведення земельної реформи була створена відповідна правова база, яка включає в загальній кількості більше сотні нормативно-правових документів: закони, постанови Верховної Ради України, постанови Кабінету Міністрів, базові накази Держкомзему тощо. Виконання вищезазначених нормативно-правових актів дало змогу здійснити більшість завдань вищезазначених етапів земельної реформи в Україні. Але в цьому нагромадженні документів щодо земельних відносин прийняті законодавчі норми та концепції не завжди підкріплювалися відповідними цільовими програмами, які, зі свого боку, не мали і на разі не мають дієвих механізмів реалізації. Так, наприклад, після прийняття Концепції Державної цільової програми розвитку земельних відносин в Україні на період до 2020 р., затвердженої розпорядженням Кабінетом Міністрів України від 17.06.2009 № 743-р, досі не прийнята сама програма, і тільки в 2017 р. зареєстровані законопроекти щодо загальнодержавних програм розвитку земельних відносин в Україні.

Крім того, сучасне земельне законодавство характеризується частими змінами провідних аспектів земельної політики, а значна кількість нормативних документів морально застаріла і не може якісно та в повному обсязі регулювати відносини, що виникають у процесі реалізації земельної реформи. Гальмується вирішення питання щодо регулювання ринку землі. Поряд з недоліками правової регламентації земельних відносин дуже повільно вирішуються проблеми адміністративної системи управління земельною сферою. Загальнодержавні дискусії щодо земельних відносин стали політичним питанням суспільства. Недосконалість нормативно-правової бази земельних відносин, механізмів ринкового обігу земельних ділянок, системи обліку земель, непрозорість процесів приватизації та відведення земельних ділянок державної та комунальної власності в оренду та приватне користування, заборона продажу земель сільськогосподарського призначення призвели до появи тіньового ринку землі. 
Останніми роками в Україні ведеться активний пошук підходів у напряму розвитку земельних відносин 3 метою формування дієвого ринку землі. Досвід країн Східної Європи при проведенні земельної реформи та розвитку сільськогосподарського виробництва показує, що однозначного вирішення цієї проблеми не існує, тому що існують різні форми власності на землю. У 90-і роки XX ст. багато держав регіону проводили реституцію націоналізованого майна, в тому числі земельних наділів. Якщо власник доводив свої права на ділянку, він міг ії отримати назад або ж продати державі.

I в Угорщині, і в Польщі були створені державні земельні органи, які виконують функції як операторів фонду земель, так і ресурсних центрів для модернізації виробництва та природоохоронного захисту земель. У країнах Східної Європи великі фермерські господарства (більше 50 га) переважають над малими, виняток становлять Румунія, Словенія, Литва. Так, у Польщі в 1997 p. 3,6 млн гектарів с/г земель була віддана в лізинг, 0,6 млн гектарів продано, а розпорядником 0,4 млн гектарів залишилося Національне земельне агентство. Більша ж частина державних агропідприємств продана $\mathrm{i}$ віддана в лізинг без дроблення. Лише незначна частина розподілена між дрібними фермерськими господарствами. Підсумовуючи, можна сказати, що при існуючому ринку продажу земель основна частина земельного фонду залишається у володінні держави, яке здає його в довгострокову оренду або лізинг. У багатьох країнах введені дуже жорсткі заходи державного регулювання ринку земель сільськогосподарського призначення.

Досвід Австралії, Данії, Іспанії, США, Франції, Швеції та інших країн у питанні функціонування ринку земель сільськогосподарського призначення показав ряд особливостей. Вони полягають у забороні на певний термін продавати землю (Іспанія, Франція, США), в отриманні дозволу уряду на купівлю сільськогосподарських земель (Швеція), встановлення максимального розміру наділу у власності сім'ї (Данія), переведення земель 3 однієї категорії в іншу тільки 3 дозволу відповідних державних органів тощо. У Норвегії державне регулювання ринку земель направлено на захист сільськогосподарських земель і створення умов для ефективного їх використання. У США частина орендованої землі становить 70\%, у Німеччині - близько $80 \%$.

Дозвільний порядок відчуження земель сільськогосподарського призначення, дія якого спрямована на ефективне використання земель і боротьбу зі спекулятивними операціями в сфері земельного обороту, давно існує також в Австрії.

Після об’єднання ФРН і НДР сільськогосподарські землі стали власністю держави, яке здає їх в оренду з правом подальшого викупу. Орендар, який придбав землю, не має права продавати ії протягом 20 років.

До основних об'єктивних проблем формування ринку землі в Україні можна віднести такі:

1. В Україні чинний кадастр земельних ресурсів $є$ недосконалим. Практично всі складові кадастру мають значні труднощі щодо їх реалізації, а сам кадастр на разі не можна вважати джерелом необхідних, достовірних і своєчасних відомостей про земельні ресурси. 
2. Процес визначення меж ділянки на місцевості (винесення в натурі) ускладнений існуючими інструкціями і неточностями між декларованими та реальними межами дільниць.

3. Парцеляція (роздробленість) земельних ресурсів. Власниками українських земель є 6,8 млн жителів села, з них 2/3 - передпенсійного і пенсійного віку, тоді як для ефективного агровиробництва потрібні великі наділи. 3 іншого боку, скорочення кількості дрібних і середніх фермерських господарств призведе до зменшення зайнятості населення в сільських районах $\mathrm{i}$ підвищення соціальної напруги.

4. Наявність великої кількості неоформленої, так званої «нічийної» землі.

Розвитку ринку сільськогосподарських земель заважають такі чинники:

- небезпека спекуляцій земельними ділянками, коли значні площі земель скуповуватимуться фінансовими спекулянтами;

- зміна цільового призначення та урбанізації сільськогосподарських земель, що призведе до зростання цін на аграрну продукцію;

- недовіра до державних органів влади через їх високу корумпованість;

- брак коштів для придбання землі і страх перед конкуренцією з аграрними холдингами;

- скуповування земель сільськогосподарського призначення іноземними державами.

- незаконне й тіньове використання землі;

- відсутність економічного та правового визначення паїв;

- недосконалість Земельного кодексу України;

- корупція у галузі земельних відносин.

Для реалізації української земельної реформи на всіх ієрархічних рівнях, як свідчить зарубіжний досвід, необхідний дієвий інструментарій, що включає нормативні, стратегічні й оперативні елементи. Якщо на нормативному рівні основну роль відіграють правила екологічного поводження, що визначають загальні обов'язки підприємств 3 виконання екологічних вимог i нормативів, то на стратегічному - системи планування, керівництва $\mathrm{i}$ контролінгу. На оперативному ж рівні використовується низка систем та інструментів, за допомогою яких виміряється і контролюється екологічна ефективність діяльності підприємства, під якою мається на увазі форма одержання результатів, що дає змогу досягти поставленої мети при мінімізації витрат ресурсів і навантаження на навколишнє природне середовище.

3 метою забезпечення успішного землекористування та управління земельними ресурсами, запровадження ринку земель в Україні необхідне:

- створення інфраструктури ринку земель сільськогосподарського призначення (земельні аукціони, земельний банк, оцінювачі, страхові компанії, землевпорядні організації, органи реєстрації прав тощо)

- запровадження «прозорого» механізму реалізації земельних ділянок, який би функціонував на засадах відкритості, рівного доступу та публічного контролю;

- налагодження ефективного функціонування Державного земельного банку — спеціалізованої державної фінансової установи, орієнтованої на 
кредитування сільськогосподарських товаровиробників під заставу землі та іншого майна;

- вдосконалення електронного Державного земельного кадастру, який би забезпечив доступ широкого загалу до інформації про об'єкти земельної власності, зокрема про межі земельних ділянок, їх цільове призначення, вид функціонального використання, нормативну грошову оцінку, розподіл між власниками і користувачами, надійну синхронізацію даних тощо;

- вдосконалення організації та підвищення якості адміністративних послуг у сфері земельних ресурсів;

- стимулювання землекористувачів до раціонального використання земельних ресурсів шляхом надання податкових і кредитних пільг особам, які здійснюють за власні кошти заходи щодо захисту земель і підвищення родючості грунтів; звільнення від плати за земельні ділянки, на яких ведуться роботи щодо поліпшення їх стану;

- створення системи вимог щодо користування сільськогосподарськими землями, включаючи екологічні вимоги та вимоги до сівозміни;

- встановлення жорстких антимонопольних обмежень та запровадження інших механізмів унеможливлення тінізації ринкового обігу земель;

- запровадження автоматизованої електронної системи обліку платників земельного податку і плати за оренду земель та фінансових трансакцій при купівлі-продажу прав власності чи прав оренди нам землю

Основними базами управління земельними ресурсами i формування земельних відносин на рівні населених пунктів у довгостроковому періоді зобов'язані стати:

- посилення системи застави та гарантій прав власності на землю;

- встановлення режиму господарської діяльності та суб'єктів права на землю місцях прибережних захисних смуг, лісозахисних смуг, прибережних смуг гідрофітних ліній, охоронних і захисних зон, зон зі спеціальними критеріями землекористування;

- розвиток стійких і результативних ринків землі, а крім того, введення повного і прозорого ринку земель;

- формування повної організаційної реєстрації власності майна на землю і нерухоме майно,

- ведення автоматизованої організації урядового земельного кадастру і забезпечення автоматизованого його ведення;

- удосконалення елементів ведення урядового земельного кадастру;

- впровадження загального координаційно-законного посвідчення на власність землею та оформлення правовстановлюючих паперів на землю;

- удосконалення урядового обліку земель для забезпечення правдивості, актуальності, повноцінності та об’єктивності даних про земельні ділянки і предмети нерухомої власності, що знаходяться на них;

- удосконалення законодавчої, нормативно-правової та інституційної бази та інструментів подальшого регулювання земельних відносин і формування відповідних умов з метою планового й стабільного обліку всіх земель України; 
- підвищення урядового контролю через використання земель, землеустрій, оцінку і прогноз земель як загальної організації взаємозалежних компонентів 3 метою прийняття адміністративних висновків;

- перетворення конфігурацій загальнодержавної звітності щодо земельних ресурсів відповідно до європейських стандартів.

Аспекти розгляду результатів проведення земельної реформи в Україні доцільно розглядати разом із проблемами реформування сільського господарства і соціального розвитку села, що ускладнює розуміння розв'язання проблеми в цілому. Отже, необхідно розглядати систему взаємопов'язаних цілей:

- формування політики, спрямованої на більш розумне застосування та раціональне використання й охорону земельних ресурсів;

- вдосконалення механізмів планування, управління і рівня оцінювання земельних ресурсів;

- посилення органів і координаційних елементів при регулюванні земельних ресурсів;

- формування елементів сприяння ефективної ролі абсолютно всіх зацікавлених сторін, зокрема територіальних громад, та необхідності забезпечення продовольчої безпеки держави в ході прийняття рішень і висновків у галузі землекористування й управління земельними ресурсами.

\section{Висновок}

Отже, одним із основних чинників виникнення проблем у системі землекористування є тривалий процес трансформації земельних відносин на території нашої країни до ринкового типу та відсутність дієвих і науково обгрунтованих механізмів реформування. Ринкові земельні відносини в Європі і світі демонструють наявність різних форм власності на землю, але для ведення сільського господарства переважно використовуються довготривала оренда землі або лізинг. Держава в таких випадках є як активним гравцем і контролером ринку землі, так і донором технічної та фінансової допомоги фермерам.

Стимулювання інвестування в землю і все створене на ній, забезпечення повноцінного функціонування ринку нерухомості в цілому, розширення фінансово-кредитного простору за рахунок іпотечного кредитування, збільшення матеріально-фінансової бази територіальних утворень - все це можливе при повноцінному земельному ринку.

Реалізація затвердженої в 2017 році Кабінетом Міністрів України Концепції розвитку фермерських господарств і сільськогосподарської кооперації на 2018 - 2020 рр. дає поштовх для активізації фермерського руху в Україні [10]. Фермерські господарства, які мають в обробітку невеликі площі, потребують підтримки, тому земельна реформа повинна бути направлена на підтримку фермерських господарств, які мають в обробітку на праві власності та користування (з урахуванням корпоративних прав) земельні ділянки загальною площею не більше 100 га.

Найбільш важливим в умовах сьогодення для України $є$ продовження трансформації земельних відносин у напряму формування інституту цивілізованого ринку землі. 


\section{Література}

1. Кадикова I.M. Формування ринку землі в умовах ринкової трансформації : автореф. дис. на здобуття наук. ступеня канд. ек. наук : спец. 08.00.01 «Економічна теорія та історія економічної думки» / Кадикова Ірина Миколаївна. - Харків, 2008. - 22 с.

2. Земельний кодекс Української РСР від 08 липипгя 1970 року № 2874-VII // Відомості Верховної Ради. — 1970. — № 29. - Ст. 205.

3. Про земельну реформу: постанова Верховної Ради України від 18 грудня 1990 року № 563-XII // Відомості Верховної Ради УРСР. — 1991. — № 10. - Ст. 100.

4. Про форми власності на землю: Закон України від 30 січня 1992 року. № 2073-XII // Відомості Верховної Ради. — 1992. — № 18. - Ст. 225.

5. Земельний кодекс України від 18 грудня 1990 року № 561-XII (втратив чинність) // Відомості Верховної Ради. - 1991. - № 10. - Ст. 98.

6. Про невідкладні заходи щодо прискорення земельної реформи у сфері сільськогосподарського виробництва: Указ Президента України від 10 листопада 1994 року № 666/94. [Електронний ресурс]. — Режим доступу : http://zakon2.rada.gov.ua/laws/show/793-94$\% \mathrm{D} 0 \% \mathrm{BF}$.

7. Про оренду землі: Закон України від 16 жовтня 1998 р. № 161- XIV [Електронний pecypc]. — Режим доступу : http://zakon3.rada.gov.ua/laws/show/161-14.

8. Про невідкладні заходи щодо прискорення реформування аграрного сектора економіки: Указ Президента України від 03 грудня 1999 року № 1529/99 [Електронний ресурс]. — Режим доступу : http://www.president.gov.ua/.

9. Державна служба статистики України [Електронний ресурс]. — Режим доступу : http://ukrstat.gov.ua/.

10. Концепція розвитку фермерських господарств та сільськогосподарської кооперації на 2018-2020 роки: Розпорядження Кабінету Міністрів України від 13 вересня 2017 року № 664-p. [Електронний ресурс]. — Режим доступу : http://zakon5.rada.gov.ua/laws/show/6642017-\%D1\%80. 